\title{
Effect of Fuel Injection Pressure Drop on Spray Characteristics in PFI Injector
}

学 ○吉田 ゆうき（同志社大）＼cjkstart正＼cjkstart松村 恵理子 （同志社大）～正 千田 二郎 （同志社大）

Yuki YOSHIDA, Doshisha University, 1-3 Tataramiyakodani, Kyotanabe-shi, Kyoto, 610-0321

Eriko MATSUMURA, Jiro SENDA, Doshisha University

The purpose of this study is to grasp the spray shape and atomization characteristics of free spray, the stage before the impingement of the spray against the wall, in order to further increase the efficiency and reduce the emission of PFI engine. This report focused on the fuel injection pressure drop and investigated the spray characteristics over the entire spray area.

\section{1 緒 言}

本研究ではポート噴射式ガソリンエンジンの更なる高 効率化および低エミッション化のために，噴霧の壁面衝突の 前段階である自由噴霧に対して噴霧形状および微粒化特性 の把握を目的とした．本報では，燃料噴射差圧変更時におけ る噴霧特性の変化を詳細に把握するため, 燃料噴射圧力およ び雾囲気圧力を変更し, 自由噴霧の可視化により, 噴霧全域 における噴霧特性の把握を行った.

\section{$2 \cdot 1$ 超高解像度撮影}

\section{2 実験装置および実験条件}

噴霧全域における噴霧の微粒化特性を把握するために超 高解像度撮影を用いた．光源には Nd：YAG レーザ（Spectra Physics : PRO200, 発光半值幅 : $8 \mathrm{~ns} /$ pulse) の第 2 高調波 $(\lambda$ $\mathrm{L}=532 \mathrm{~nm}$ ）を用いた．発振されたレーザ光はピンホールを介 して, 干渉縞を低減するスペックル低減装置 (ナノフォトン: スペックルキラー, SK-11， $\phi=10 \mathrm{~mm} ）$ に入射される. スペッ クル低減装置より出射されたレーザ光は, 平凸レンズ $(\mathrm{f}=200 \mathrm{~mm})$ ，両凸レンズ $(\mathrm{f}=300 \mathrm{~mm})$ および平凸レンズ $(\mathrm{f}=1000 \mathrm{~mm})$ の順に通過し集光されながら噴霧に照射され る．噴霧を透過したレーザ光は超高解像度レンズ系により捉 えられ, 受光面上に拡大結像される. 拡大倍率は 2.7 倍, 空 間分解能は $9.8 \mu \mathrm{m}$ とした. また, 本実験において, インジェ クタは噴孔が同一ピッチ円上に等間隔に配置されている 10 孔ホールノズルを使用した.

\section{$2 \cdot 2$ 実験条件}

表 1 に実験条件を示す．本実験では，噴射差圧をメインパ ラメータとし，同等の噴射差圧となるように燃料噴射圧力 （実験条件 I）または雾囲気圧力（実験条件 II）を変更し実 験を行った. また, 噴射差圧が $324 \mathrm{kPa}$, 䨌囲気圧力が大気圧, 燃料噴射圧力が $424 \mathrm{kPa}$ の条件を基準条件とした.

Table 1 Experimental conditions

\begin{tabular}{|c|c|c|}
\hline & $\begin{array}{l}\text { Experimental conditions I } \\
\text { Change of } P_{\underline{m i} i}\end{array}$ & $\begin{array}{c}\text { Experimental conditions II } \\
\text { Change of } P_{a}\end{array}$ \\
\hline Test fuel & \multicolumn{2}{|c|}{ iso-Octane } \\
\hline Test nozzle & \multicolumn{2}{|c|}{ Multi hole nozzle (10 holes) } \\
\hline Ambient gas & \multicolumn{2}{|c|}{$\mathrm{N}_{2}$} \\
\hline Injection pressure drop $\triangle P[\mathrm{kPa}]$ & \multicolumn{2}{|c|}{$394,374,324,274,224$} \\
\hline Ambient density & 1.15 & $0.34,0.57,1.15,1.73,2.30$ \\
\hline Ambient pressure & 100 & $30,50,100,150,200$ \\
\hline Ambient temperature & \multicolumn{2}{|c|}{ room temperature } \\
\hline Injection pressure & $494,474,424,374,324$ & 424 \\
\hline Fuel temperature & \multicolumn{2}{|c|}{ room temperature } \\
\hline Injection duration & $5.41,5.54,6.00,6.05,6.64$ & $5.28,5.42,6.00,6.41,7.31$ \\
\hline Injection quantity & \multicolumn{2}{|c|}{10.1} \\
\hline
\end{tabular}

\section{3 実験結果および考察}

\section{$3 \cdot 1$ 噴霧全域における微粒化特性}

図 1 に，燃料噴射圧力変更時および雰囲気圧力変更時にお けるザウタ平均粒径と噴射差圧の関係図を示す．解析対象は $t / t_{i n j}=0.7$ における噴霧全域とした。 $t / t_{i n j}$ とは，噴射開始から の時間を噴射期間で除して正規化した值である．また，ザウ タ平均粒径に関しては, 式 (1) のような実験式が提案されて いる(1).

$D_{32}=2.33 \cdot 10^{3}(\Delta P)^{-0.135}\left(\rho_{a}\right)^{0.121}(Q)^{0.131}$

ただし， $D_{32}$ はザウタ平均粒径， $Q$ は噴射量を示し, 本実験で は全ての条件において噴射量を一定としている．燃料噴射圧 力変更時においては雰囲気密度も一定としている. 図 1 より, 噴射差圧の増加に伴う微粒化の促進が確認でき，これは噴射 差圧の増加に伴い, 噴霧の噴出速度が増加し, 噴霧と周囲気 体との間に働くせん断力が増加したためであると考えられ る.したがって，低圧噴霧においてもザウタ平均粒径は噴射 差圧に対して負の相関をとることが確認でき， -0.31 の指数 值となる，また図 1 において，噴射差圧が同等の条件におけ るザウタ平均粒径を比較すると, ザウタ平均粒径はおおむね 一致していることが確認できる，このことから，噴霧全域に おけるザウタ平均粒径は雰囲気密度に対する影響度が小さ いことがわかり， 0.01 程度の指数值となる. 雾囲気密度増加 に伴い，噴霧と周囲気体との間にはたらくせん断力の増加に より噴霧の微粒化が促進する一方で, 抗力の増加により噴霧 の速度減衰が生じ，これらの影響が相殺することで影響度が 小さくなったと考えられる.

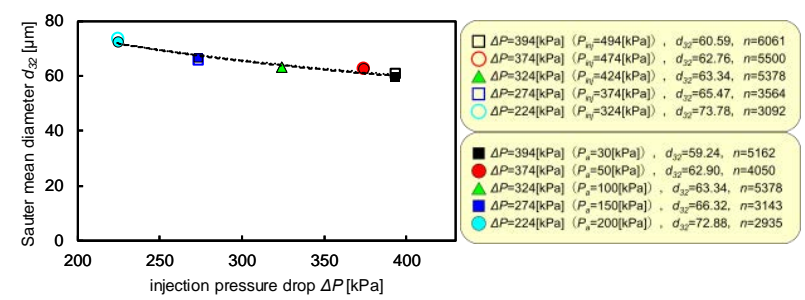

Fig.1 Correlation between sauter mean diameter and injection pressure drop in the entire spray area $(t / t i n j=0.7)$

\section{4 結 言}

実験的解析によって，ポート噴射式ガソリンエンジンを対 象とした噴霧全域における微視的な噴霧特性を把握するた め, 超高解像度撮影系を用いて自由噴霧の直接撮影を行った. 得られた知見を以下に示す.

（1）噴霧全域において, 噴射差圧の増加に伴ってザウタ平均 粒径は小さくなり，微粒化が促進される.

(2) 噴霧全域において, 噴射差圧は雾囲気密度と比較してザ ウタ平均粒径に与える影響度は大きい.

\section{参考文献}

(1) Hiroyasu.H, Kadota.T, "Fuel Droplet Size Distribution in Diesel Combustion Chamber", SAE Paper 740715,1974 